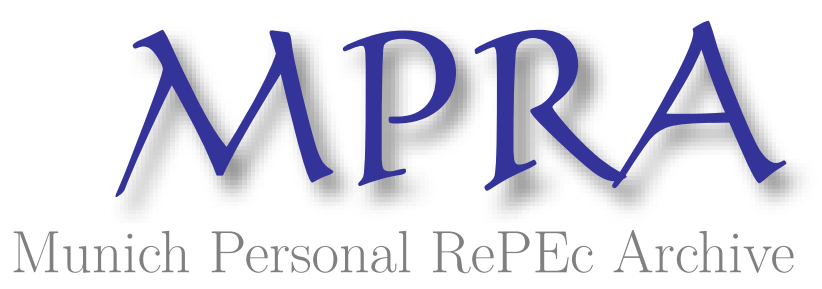

\title{
Output, renewable and non-renewable energy consumption and international trade: Evidence from a panel of 69 countries
}

Ben Jebli, Mehdi and Ben Youssef, Slim

Jendouba University, FSEG de Tunis, LAREQUAD, Manouba University, ESC de Tunis, LAREQUAD

May 2013

Online at https://mpra.ub.uni-muenchen.de/51199/

MPRA Paper No. 51199, posted 05 Nov 2013 18:57 UTC 


\title{
Output, renewable and non-renewable energy consumption and international trade: Evidence from a panel of 69 countries
}

\author{
Mehdi Ben Jebli \\ LAREQUAD \& FSEGT, University of Tunis El Manar, Tunisia \\ University of Jendouba, ISI du Kef, Tunisia \\ benjebli.mehdi@gmail.com \\ (00216) 21040246 \\ Slim Ben Youssef* \\ Manouba University, ESC de Tunis, LAREQUAD \\ Campus Universitaire, Manouba 2010, Tunisia \\ (00216) 97363596 \\ slim.benyoussef@gnet.tn
}

First version: May, 2013

This version: November, 2013

\begin{abstract}
This paper uses panel cointegration techniques to examine the causal relationship between output, renewable and non-renewable energy consumption, and international trade for a sample of 69 countries during the period 1980-2007. In the short-run, Granger causality tests show that there is evidence of a bidirectional causality between output and trade (exports or imports), a one way causality running from renewable energy consumption to trade, and a bidirectional feedback causality between non-renewable energy consumption and trade. Interestingly, there is no direct short-run causality between the three variables renewable energy, non-renewable energy and output. However, there is an indirect short-run causality running from renewable energy to both non-renewable energy and output, which occurs through trade. Also, there is an indirect and bidirectional short-run causality between non-renewable energy and output through trade. In the long-run, OLS, FMOLS and DOLS estimates suggest that renewable and non-renewable energy consumption and trade have a positive and statistically significant impact on economic growth. Our policy recommendations are to encourage trade openness because this may reduce the share of nonrenewable energy consumption in total energy consumption. Indeed, through technology transfer and economies of scale, more trade openness could be a good policy for combating global warming by encouraging the use of renewable energies, while increasing output.
\end{abstract}

Keywords: Renewable and non-renewable electricity consumption; Trade openness; Panel cointegration.

JEL Classification: C33, F14, Q43

\footnotetext{
* Corresponding author.
} 


\section{Introduction}

This paper investigates the interaction between international trade and renewable and nonrenewable energy consumption by considering a panel of 69 countries. This investigation is interesting because the causal relationship between renewable and non-renewable energy and international trade has not been previously studied. Nevertheless, it is admitted that the use of renewable energy is linked to technology transfer, which is directly linked to international trade. The Rio and Johannesburg conferences recognized that trade helps achieving more efficient allocation of scarce resources, makes it easier for rich and poor countries to access environmental goods, services and technologies (World Trade Organization, 2011).

Several empirical studies analyze the causal relationship between economic growth and the consumption of renewable energy (e.g. Apergis and Payne, 2010a, 2010b, 2011, 2012, Sadorsky, 2009b). Another group of papers analyze the causal relationship between economic growth, renewable energy consumption and $\mathrm{CO}_{2}$ emissions (e.g. Sadorsky, 2009a). All these studies support that renewable energy consumption plays an important role in increasing economic growth. Moreover, an energy policy planned to increase the share of renewable energy in total energy consumption is very effective in reducing greenhouse gas emissions. In addition to capital, labor, and renewable energy consumption, other variables such as trade openness can be incorporated into the production function to explain the growth of gross domestic product (GDP). Trade openness can be defined as exports, or imports, or the sum of both divided by the value of GDP.

Several papers study the causal relationship between energy consumption (total energy use), international trade, and output. Lean and Smyth (2010a) study the dynamic relationship between economic growth, electricity production, exports and prices in Malaysia. Granger causality tests show the existence of a unidirectional causality running from economic growth to electricity production. Lean and Smyth (2010b) study the causal relationship, in Malaysia, between output, electricity consumption, exports, labor, and capital in a multivariate model. They show the existence of a bidirectional causality between output and electricity consumption. They come to the conclusion that Malaysia should adopt the strategy of increasing investment in electricity infrastructure and encouraging electricity conservation policies to reduce unnecessary use of electricity. Narayan and Smyth (2009) come to the same conclusion for a sample of Middle East countries and find feedback effects between electricity consumption, exports and GDP. Sadorsky (2011) uses panel cointegration techniques for 8 Middle East countries to study how trade can affect energy consumption. He finds a Granger causality running from exports to energy consumption and a bidirectional causality between imports and energy consumption in the short-run. In the long-run, he finds that an increase in both exports and imports affect the demand of energy. Another study on a sample of 7 South American countries, Sadorsky (2012), confirms the long-run causality between trade and energy consumption. He concludes that environmental policies made to reduce energy consumption will reduce trade.

To the best of our knowledge, there is no study that tries to evaluate the causal relationship between international trade and renewable and non-renewable energy consumption. The aim of this paper is to explore the causal relationship between renewable energy consumption, non-renewable energy consumption, trade, and output by considering a panel of 69 countries.

This study has the following structure. Section 2 gives an idea about the renewable energy sector and international trade. Section 3 describes the data used. Section 4 deals with the methodology used and the empirical analysis. Finally, Section 5 concludes. 


\section{Renewable energy and international trade}

According to the International Energy Agency (2012), more than 70 countries are expected to use renewable energy technologies in the power sector by 2017 . One policy driver is environmental concerns which aim to reduce the emission of carbon dioxide (CO2) and local pollutants. Renewables are also encouraged to stimulate economies, reinforce energy security and diversify energy consumption. Renewable energies have been used principally by the electricity sector, followed by biofuels. In most cases, subsidies are needed because renewables are still more expensive than conventional energy sources.

Renewable energy use, including traditional biomass, was 1684 million tons of oil equivalent (Mtoe) in 2010 representing 13\% of total primary energy use. This share has remained stable since 2000, but contributions of the different renewable sources have changed. The share of traditional biomass in total renewable energy decreased from $50 \%$ in 2000 to $45 \%$ in 2010, while biofuels made an increasing share in the transportation fuel needs. The share of hydropower, the largest source of renewable electricity, remained stable. The most important increases are those of electricity generation from wind which increased by $27 \%$ and solar photovoltaic (PV) which increased by $42 \%$ per year on average during the period 2000-2010. The renewables sector has been affected by the international economic crisis. However, weaker performances in some regions, for example, in some regions in Europe and the United States, have been largely offset by important increase in the rest of the world, notably in Asia.

Because of government support, decreasing costs, $\mathrm{CO} 2$ pricing in some regions, and rising fossil fuel prices in the long-term, the International Energy Agency (2012) estimates that the share of renewables in primary energy use will increase. Electricity generation from renewable will approximately triple from 2010 to 2035, attaining $31 \%$ of total production. In 2035 , hydropower will provide half of renewable production, wind nearly one-quarter and solar photovoltaic 7.5\%. Solar PV production will increase 26-fold from 2010 to 2035 . The use of renewables is expected to reduce $\mathrm{CO} 2$ emissions by over than $4.1 \mathrm{Gt}$ in 2035, contribute to the diversification of the energy sources, lower oil and gas import bills, and diminish air pollution.

The United Nations Environment Program and the World Trade Organization (2009) consider that the 60 years prior to 2008 have been marked by a considerable expansion of international trade. In terms of volume, world trade is approximately 32 times greater now than it was in 1950. The share in total GDP increased from 5.5 per cent in 1950 to 21 per cent in 2007. This considerable expansion in world trade has been encouraged by technological progress, which has considerably reduced the costs of transportation and communications, and by the use by countries of more open trade and investment policies. The number of countries participating in international trade has increased. For instance, developing countries have approximately doubled their share in international trade in the last 60 years. This expansion in international trade poses questions about its impact on greenhouse gas emissions. The impact of trade on pollution can be explained by three principal effects, which are the scale, composition and technique effects. International trade can be used as a channel for diffusing technologies, especially from developed to developing countries, to combat climate change. International trade can increase the availability of goods and services that are more energy efficient. The increase in income made possible by trade openness can lead to a demand for a better environmental quality and to a diminution of greenhouse gas emissions.

In conclusion, the production of renewable energies is increasing in all parties of the world and this is the same for international trade. It is admitted that international trade helps the use and diffusion of renewable technologies. However, this should be verified empirically. 


\section{Data}

The data set is a panel of 69 countries followed over the years 1980-2007 and includes annual data on output, renewable and non-renewable electricity consumption, capital, labor, exports, and imports. The Appendix lists the 69 countries included in the analysis which are distributed on the five continents. Annual time series data are chosen to include as many countries as possible by taking into account the availability of data over the selected period. The multivariate framework for the analysis includes real gross domestic product (GDP, output) measured in constant 2000 US dollars. Renewable energy consumption (RE) is the total renewable electricity consumption measured in millions of kilowatt hours. It comprises the electricity produced from geothermal, solar, wind, tide and wave, biomass and waste, and hydroelectric. Non-renewable energy consumption (NRE) is the total non-renewable electricity produced using oil, natural gas and coal, and is measured in millions of kilowatt hours. Exports (imports) are measured using merchandise exports (imports) in current US dollars and are converted to real values by dividing them by the price level of consumption (PC). The capital stock is measured by the gross fixed capital formation in constant 2000 US dollars. Labor is measured as the total number of labor force. Data on exports, imports, capital and labor are obtained from the World Bank (2010). Data on renewable and non-renewable energy consumption are obtained from the U.S. Energy Information Administration (2012), and those on PC are obtained from the Penn World Table version 7.1 (Heston et al., 2012). All estimations are made using Eviews 7.0.

\section{Methodology and empirical analysis}

Following Apergis and Payne (2011, 2012), Lean and Smith (2010a, 2010b), and Sadorsky (2012), we estimate the relationship between renewable and non-renewable energy consumption, output and trade by using the production function. The model in Apergis and Payne (2012) includes renewable and non-renewable energy in the production function in order to investigate the links between energy and output. The model in Sadorsky (2012) includes exports and imports in two separate empirical models, whereas the models in Lean and Smith (2010a, 2010b) include only exports. In the present paper, we follow the same model specification than Sadorsky (2012) to investigate the relationship between renewable and non-renewable energy consumption, output and trade.

The production modeling framework given below shows that output $(Y)$ is written as a function of renewable and non-renewable energy $(R E, N R E)$, trade openness $(O)^{1}$, capital $(K)$, and labor $(L)$ :

$$
Y_{i t}=f\left(R E_{i t}, N R E_{i t}, O_{i t}, K_{i t}, L_{i t}\right)
$$

Eq. (1) can be written as follow:

$$
Y_{i t}=R E_{i t}^{\beta_{1 i}} N R E_{i t}^{\beta_{2 i}} O_{i t}^{\beta_{3 i}} K_{i t}^{\beta_{4 i}} L_{i t}^{\beta_{5 i}}
$$

The natural log of Eq. (2) gives the following equation:

$$
y_{i t}=\alpha_{i}+\delta_{i} t+\beta_{1 i} r e_{i t}+\beta_{2 i} n r e_{i t}+\beta_{3 i} o_{i t}+\beta_{4 i} k_{i t}+\beta_{5 i} l_{i t}+\varepsilon_{i t}
$$

\footnotetext{
${ }^{1}$ Trade openness is incorporated into the production function by including real exports or real imports of merchandises in two separate specification models because of the high correlation value (0.97) between exports (ex) and imports (im).
} 
where $i=1, \ldots, N$ for each country in the panel, $t=1, \ldots, T$ denotes the time period and $(\varepsilon)$ denotes the stochastic error term. The parameters $\alpha_{i}$ and $\delta_{i}$ allow for the possibility of country-specific fixed effect and deterministic trend, respectively.

To examine the relationship between renewable and non-renewable energy consumption and trade for a sample of 69 countries, we use panel cointegration techniques. These techniques are interesting because estimations from cross-sections of time series have more freedom degrees and are more efficient than estimations from individual time series. Panel cointegration techniques are particularly useful when the time series dimension of each crosssection is short. Our empirical analysis follows four steps: $i$ ) we proceed panel unit root tests for stationary, $i i$ ) we look for long-term cointegration between variables, iii) we estimate the long-run relationships between variables, and $i v$ ) we study the causality between variables using Engle and Granger (1987) approach.

\subsection{Stationary tests}

In this study four types of unit root tests are computed in order to examine the order of integration of variables at level and at first difference: Levin et al. (2002), Im et al. (2003), tests of Fisher using augmented Dickey and Fuller (ADF) (1979), and Phillips and Perron (1988). These tests are divided in two groups. The first group of tests includes LLC's test (Levin et al., 2002) that assumes a common unit root process across the cross-section. The other tests are IPS-W-statistic (Im et al., 2003), Fisher-ADF Chi-square (Dickey and Fuller, 1979) and Fisher-PP Chi-square (Phillips and Perron, 1988) are included in the second group and assume individual unit root process across the cross-section. For all these tests, the null hypothesis is that there is a unit root and the alternative hypothesis is that there is no unit root. We assume that the test regressions contain an intercept and no deterministic trend. The numbers of lags selected are selected automatically using Schwarz Information Criterion (SIC). The results of unit root tests are reported in Table 1.

Table 1. Panel unit root tests

\begin{tabular}{lllll}
\hline Panel unit root test method & LLC & IPS & Fisher-ADF & Fisher-PP \\
\hline$y$ & 6.53103 & 16.9322 & 27.9805 & 29.1039 \\
& $(1.0000)$ & $(1.0000)$ & $(1.0000)$ & $(1.0000)$ \\
$\Delta y$ & -19.9102 & -20.7862 & 664.983 & 669.754 \\
& $(0.0000)^{\mathrm{a}}$ & $(0.0000)^{\mathrm{a}}$ & $(0.0000)^{\mathrm{a}}$ & $(0.0000)^{\mathrm{a}}$ \\
\hline$r e$ & -3.88498 & -2.04254 & 217.292 & 262.121 \\
& $(0.0000)^{\mathrm{a}}$ & $(0.0205)$ & $(0.0000)^{\mathrm{a}}$ & $(0.0000)^{\mathrm{a}}$ \\
$\Delta r e$ & -34.7766 & -37.1259 & 1239.34 & 1396.95 \\
& $(0.0000)^{\mathrm{a}}$ & $(0.0000)^{\mathrm{a}}$ & $(0.0000)^{\mathrm{a}}$ & $(0.0000)^{\mathrm{a}}$ \\
\hline$n r e$ & -1.45649 & 6.16964 & 94.1782 & 103.004 \\
& $(0.0726)$ & $(1.0000)$ & $(0.9984)$ & $(0.9886)$ \\
$\Delta n r e$ & -31.1550 & -32.8946 & 1109.17 & 1338.54 \\
& $(0.0000)^{\mathrm{a}}$ & $(0.0000)^{\mathrm{a}}$ & $(0.0000)^{\mathrm{a}}$ & $(0.0000)^{\mathrm{a}}$ \\
\hline$k$ & 4.11696 & 8.83988 & 55.9864 & 37.5331 \\
& $(1.0000)$ & $(1.0000)$ & $(1.0000)$ & $(1.0000)$ \\
$\Delta k$ & -22.5516 & -23.0878 & 752.298 & 737.308 \\
& $(0.0000)^{\mathrm{a}}$ & $(0.0000)^{\mathrm{a}}$ & $(0.0000)^{\mathrm{a}}$ & $(0.0000)^{\mathrm{a}}$ \\
\hline$l$ & -11.9254 & 3.47584 & 177.046 & 267.188
\end{tabular}




\begin{tabular}{lllll} 
& $(0.0000)^{\mathrm{a}}$ & $(0.9997)$ & $(0.0140)$ & $(0.0000)^{\mathrm{a}}$ \\
& -9.00573 & -12.7521 & 486.933 & 492.611 \\
& $(0.0000)^{\mathrm{a}}$ & $(0.0000)^{\mathrm{a}}$ & $(0.0000)^{\mathrm{a}}$ & $(0.0000)^{\mathrm{a}}$ \\
\hline ex & 0.39704 & 9.92898 & 44.2421 & 40.1834 \\
\multirow{4}{*}{$\Delta e x$} & $(0.6543)$ & $(1.0000)$ & $(1.0000)$ & $(1.0000)$ \\
& -30.1456 & -30.3572 & 1014.52 & 1135.34 \\
im & $(0.0000)^{\mathrm{a}}$ & $(0.0000)^{\mathrm{a}}$ & $(0.0000)^{\mathrm{a}}$ & $(0.0000)^{\mathrm{a}}$ \\
\hline \multirow{3}{*}{$\Delta i m$} & 4.60742 & 14.2231 & 18.0246 & 17.5201 \\
& $(1.0000)$ & $(1.0000)$ & $(1.0000)$ & $(1.0000)$ \\
& -31.5097 & -29.9565 & 997.782 & 1085.92 \\
& $(0.0000)^{\mathrm{a}}$ & $(0.0000)^{\mathrm{a}}$ & $(0.0000)^{\mathrm{a}}$ & $(0.0000)^{\mathrm{a}}$ \\
\hline
\end{tabular}

Null hypothesis: Unit root.

All unit root tests regressions are run with intercept.

P-value listed in parentheses. Critical value at the $1 \%$ significance level denoted by "a".

Automatic lag length selection based on SIC (Schwarz Information Criteria).

Table 1 indicates that, at level, there is a unit root for $y, n r e c, k$, ex, and im panel data series, whereas after first difference, all our variables are integrated of order one, I(1). For ( $r e$ ) data series, the result from the IPS (Im et al. (2003)) test provides the presence of a unit root at level, whereas after first difference it confirms that renewable energy consumption is integrated of order one at the $1 \%$ significance level. Using IPS and ADF tests, labor force $(l)$ contains a unit root at level but becomes stationary after first difference. Finally, we can conclude that the stationary of each variable is established and our results confirm that the integration order is one.

\subsection{Cointegration tests}

To check for long-run association in a heterogeneous panel, we use the Pedroni's (1999, 2004) cointegration tests. Pedroni (2004) proposes seven statistics distributed on two sets of cointegration tests. The first set comprises four panel statistics and includes v-statistic, rhostatistic, PP-statistic and ADF-statistic. These statistics are classified on the within-dimension and take into account common autoregressive coefficients across countries. The second set comprises three group statistics and includes rho-statistic, PP-statistic, and ADF statistic. These tests are classified on the between-dimension and are based on the individual autoregressive coefficients for each country in the panel. The null hypothesis is that there is no cointegration $\left(H_{0}: \rho_{i}=1\right)$, whereas the alternative hypothesis is that there is cointegration between variables. Panel cointegration tests of Pedroni (2004) are based on the residual of Eq. (3). The estimated residuals are defined as follows:

$$
\hat{\varepsilon}_{i t}=\rho_{i} \hat{\varepsilon}_{i t-1}+w_{i t}
$$

We assume that the tests are running with individual intercept and deterministic trend. The results from the tests for the data set for the model with exports and the model with imports are reported in Tables 2 and 3, respectively. 
Table2. Pedroni cointegration tests (with exports)

\begin{tabular}{|c|c|c|c|c|}
\hline \multicolumn{5}{|c|}{ Alternative hypothesis: common AR coefs. (within-dimension) } \\
\hline & & & \multicolumn{2}{|l|}{ Weighted } \\
\hline & Statistic & Prob. & Statistic & Prob. \\
\hline Panel v-Statistic & 3.000609 & $0.0000 * * *$ & 2.956833 & $0.0000 * * *$ \\
\hline Panel rho-Statistic & 2.998403 & 0.9986 & 2.793275 & 0.9974 \\
\hline Panel PP-Statistic & -2.981728 & $0.0014 * * *$ & -2.849749 & $0.0022 * * *$ \\
\hline Panel ADF-Statistic & -3.271644 & $0.0000 * * *$ & -3.192934 & $0.0007 * * *$ \\
\hline \multicolumn{5}{|c|}{ Alternative hypothesis: individual AR coefs. (between-dimension) } \\
\hline & Statistic & Prob. & & \\
\hline Group rho-Statistic & 5.459964 & 1.0000 & & \\
\hline Group PP-Statistic & -3.660259 & $0.0001 * * *$ & & \\
\hline Group ADF-Statistic & -3.927177 & $0.0000 * * *$ & & \\
\hline
\end{tabular}

Null Hypothesis: No cointegration

Trend assumption: Deterministic intercept and trend.

Critical value at the $1 \%$ significance level is denoted by “***".

Automatic lag length selection based on SIC with a max lag of 5.

Newey-West automatic bandwidth selection and Bartlett kernel.

Table 2 indicates that, for the model with exports, three panel statistics (v-statistic, PPstatistic and ADF-statistic) among the four statistics used of the within-dimension, reject the null hypothesis of no cointegration at the $1 \%$ significance level and approve that there is evidence of cointegration between variables. Two group statistics (PP-statistic and ADFstatistic) among the three statistics used of the between-dimension reject the null hypothesis of no cointegration at the $1 \%$ significance level and approve the existence of cointegration between variables. Therefore, five tests among seven confirm the existence of long-term cointegration between the variables.

Table 3. Pedroni cointegration tests (with imports)

\begin{tabular}{|c|c|c|c|c|}
\hline & & & Weighted & \\
\hline & Statistic & Prob. & Statistic & Prob. \\
\hline Panel v-Statistic & 3.085872 & $0.0012 * * *$ & 3.047974 & $0.0012 * * *$ \\
\hline Panel rho-Statistic & 3.652326 & 0.9999 & 3.489442 & 0.9998 \\
\hline Panel PP-Statistic & -2.708324 & $0.0034 * * *$ & -2.076545 & $0.0189 * *$ \\
\hline Panel ADF-Statistic & -3.022099 & $0.0013 * * *$ & -2.504795 & $0.0061 * * *$ \\
\hline \multicolumn{5}{|c|}{ Alternative hypothesis: individual AR coefs. (between-dimension) } \\
\hline & Statistic & Prob. & & \\
\hline Group rho-Statistic & 6.203968 & 1.0000 & & \\
\hline Group PP-Statistic & -2.493555 & $0.0063 * * *$ & & \\
\hline Group ADF-Statistic & -2.450293 & $0.0071 * * *$ & & \\
\hline
\end{tabular}

Null Hypothesis: No cointegration

Trend assumption: Deterministic intercept and trend.

Critical values at the $1 \%$ and $5 \%$ significance levels denoted by “***” and “**”, respectively.

Automatic lag length selection based on SIC with a max lag of 5.

Newey-West automatic bandwidth selection and Bartlett kernel.

For the model with imports, Table 3 indicates that, among the four used statistics of the within-dimension, three panel statistics (v-statistic, PP-statistic and ADF-statistic) reject the null hypothesis of no cointegration at the $1 \%$ significance level. Two group statistics (PP- 
statistic and ADF-statistic) among the three statistics used from the between-dimension reject the null hypothesis of no cointegration at the 1\% significance level. Thus, the Pedroni (2004) tests confirm the existence of long-term cointegration between the variables.

\subsection{Long-run estimations}

This step consists in the long-run estimation of Eq. (3) where the dependent variable is real GDP or output, and the independent variables are renewable energy consumption, nonrenewable energy consumption, real exports (or imports), capital stock and labor force. The ordinary least squares (OLS) estimator is asymptotically biased and its distribution depends on nuisance parameters, in the context of a panel estimate. To correct this bias, we estimate the long-run structural coefficients of Eq. (3) by using the fully modified OLS (FMOLS) and the dynamic OLS (DOLS) panel approaches proposed by Pedroni (2001, 2004). To correct for the problems of endogeneity and serial correlation, FMOLS uses a non-parametric approach, whereas DOLS uses a parametric approach. As our variables are measured in natural logarithms, the coefficients estimated from the long-run cointegration relationship can be considered as long-run elasticities. The results of long-run estimates for the model with exports and that with imports are reported in Tables 4 and 5, respectively.

Table 4. Panel OLS-FMOLS-DOLS long-run estimates (model with exports)

\begin{tabular}{|c|c|c|c|c|c|}
\hline Variables & re & nre & $e x$ & $k$ & $l$ \\
\hline & 0.040250 & 0.113815 & 0.033148 & 0.725328 & 0.076066 \\
\hline \multirow[t]{2}{*}{ OLS } & $(0.0000)^{* * * *}$ & $(0.0000)^{* * *}$ & $(0.0000) * * *$ & $(0.0000)^{* * * *}$ & $(0.0000)^{* * *}$ \\
\hline & 0.040625 & 0.089270 & 0.011540 & 0.788769 & 0.058852 \\
\hline \multirow[t]{2}{*}{ FMOLS } & $(0.0000)^{* * *}$ & $(0.0002)^{* * *}$ & $(0.5694)$ & $(0.0000)^{* * *}$ & $(0.0000) * * *$ \\
\hline & 0.040250 & 0.113815 & 0.033148 & 0.725328 & 0.076066 \\
\hline DOLS & $(0.0002)^{* * *}$ & $(0.0000)^{* * *}$ & $(0.1059)$ & $(0.0000)^{* * * *}$ & $(0.0000)^{* * *}$ \\
\hline
\end{tabular}

Cointegrating equation deterministics: intercept and trend.

Critical value at the $1 \%$ significance level is denoted by “****.

All variables are measured in natural logarithms.

Table 4 reports the results for panel OLS, FMOLS and DOLS long-run estimates for Eq. (3) with exports. For the renewable energy, non-renewable energy, capital and labor variables, the three approaches produce very close results in terms of sign, magnitude and statistical significance. ${ }^{2}$ Indeed, their estimated coefficients are statistically significant at the $1 \%$ level and indicating a positive impact on output. The estimated coefficient of exports is not statistically significant under FMOLS and DOLS approaches, but is statistically significant at the $1 \%$ level under the OLS approach with a positive impact on output.

By using the FMOLS approach, a $1 \%$ increase in renewable energy increases output by $0.04 \%$, a $1 \%$ increase in non-renewable energy increases output by $0.09 \%$, a $1 \%$ increase in capital increases output by $0.79 \%$, and a $1 \%$ increase in labor increases output by $0.06 \%$. By using the OLS approach, a $1 \%$ increase in exports increases output by $0.03 \%$.

\footnotetext{
${ }^{2}$ According to Banerjee (1999), the FMOLS and DOLS long-run estimates are asymptotically similar when we have more than 60 observations. Our panel data comprises 1932 observations.
} 
Table 5. Panel OLS-FMOLS-DOLS long-run estimates (model with imports)

\begin{tabular}{lccccc}
\hline Variables & $\boldsymbol{r e}$ & $\boldsymbol{n} \boldsymbol{e} \boldsymbol{i}$ & $\boldsymbol{i m}$ & $\boldsymbol{k}$ & $\boldsymbol{l}$ \\
\hline OLS & 0.041878 & 0.112659 & 0.048148 & 0.717723 & 0.072206 \\
& $(0.0000)^{* * *}$ & $(0.0000)^{* * *}$ & $(0.0000)^{* * *}$ & $(0.0000) * * *$ & $(0.0000)^{* * *}$ \\
\hline FMOLS & $(0.042188$ & 0.082159 & 0.042819 & 0.770815 & 0.057262 \\
& 0.041878 & 0.112659 & 0.048148 & 0.717723 & 0.072206 \\
DOLS & $(0.0000)^{* * * *}$ & $(0.0000)^{* * *}$ & $(0.0446) * *$ & $(0.0000) * * *$ & $(0.0001)^{* * *}$ \\
\hline Coint
\end{tabular}

Cointegrating equation deterministics: intercept and trend.

Critical values at the $1 \%, 5 \%$ and $10 \%$ significance levels denoted by “***”, “**” and “*”, respectively.

All variables are measured in natural logarithms.

Table 5 reports the results for panel OLS, FMOLS and DOLS long-run estimates for Eq. (3) with imports. For all variables, except the import variable, the three approaches produce very close results in terms of sign, magnitude and statistical significance. Indeed, their estimated coefficients are statistically significant at the $1 \%$ level and indicate a positive impact on output. The estimated coefficients of imports are very close and indicate a positive impact on output with a statistical significance at the 1\%,10\% and 5\% levels with the OLS, FMOLS and DOLS approaches, respectively.

In the long-run, FMOLS estimation results suggest that a $1 \%$ increase in renewable energy consumption increases output by $0.04 \%$, a $1 \%$ increase in non-renewable energy consumption increases output by $0.08 \%$, a $1 \%$ increase in imports increases output by $0.04 \%$, a $1 \%$ increase in capital increases output by $0.77 \%$, and a $1 \%$ increase in labor increases output by $0.06 \%$.

For all variables except the export and import variables, the computed coefficients for the model with exports and that with imports are very similar in terms of sign, magnitude and statistical significance, and lead to the same conclusions. These long-run estimates are very different from that found by Apergis and Payne (2012) because our estimated coefficients are relatively very small for the renewable energy, non-renewable energy, and labor variables. We think that this difference is due to the integration of trade openness as a dependent variable in our specified model.

\subsection{Causality tests}

Given that the residual cointegration tests of Pedroni $(1999,2004)$ show the existence of a long-run relationship between variables for the two specific models (exports or imports), then the approach of Engle and Granger (1987) can be used to estimate the error correction model. Our analysis will focus principally on the output, renewable energy consumption, nonrenewable energy consumption, exports, and imports variables.

The estimation of the dynamic vector error correction model (VECM) is given as follows:

$$
\begin{aligned}
& \Delta y_{i t}=\theta_{1 i}+\sum_{j=1}^{q} \theta_{1,1 i j} \Delta y_{i t-j}+\sum_{j=1}^{q} \theta_{1,2 i j} \Delta r e_{i t-j}+\sum_{j=1}^{q} \theta_{1,3 i j} \Delta n r e_{i t-j}+\sum_{j=1}^{q} \theta_{1,4 i j} \Delta o_{i t-j}+\sum_{j=1}^{q} \theta_{1,5 i j} \Delta k_{i t-j} \\
& +\sum_{j=1}^{q} \theta_{1,6 i j} \Delta l_{i t-j}+\lambda_{1 i} E C T_{i t-1}+\mu_{1 i t} \\
& \Delta r e_{i t}=\theta_{2 i}+\sum_{j=1}^{q} \theta_{2,1 i j} \Delta y_{i t-j}+\sum_{j=1}^{q} \theta_{2,2 i j} \Delta r e_{i t-j}+\sum_{j=1}^{q} \theta_{2,3 i j} \Delta n r e_{i t-j}+\sum_{j=1}^{q} \theta_{2,4 i j} \Delta o_{i t-j}+\sum_{j=1}^{q} \theta_{2,5 i j} \Delta k_{i t-j}
\end{aligned}
$$




$$
\begin{aligned}
& \sum_{j=1}^{q} \theta_{2,6 i j} \Delta l_{i t-j}+\lambda_{2 i} E C T_{i t-1}+\mu_{2 i t} \\
& \Delta n r e_{i t}=\theta_{3 i}+\sum_{j=1}^{q} \theta_{3, i j} \Delta y_{i t-j}+\sum_{j=1}^{q} \theta_{3,2 i j} \Delta r e_{i t-j}+\sum_{j=1}^{q} \theta_{3,3 i j} \Delta n r e_{i t-j}+\sum_{j=1}^{q} \theta_{3,4 i j} \Delta o_{i t-j}+\sum_{j=1}^{q} \theta_{3,5 i j} \Delta k_{i t-j} \\
& \sum_{j=1}^{q} \theta_{3,6 i j} \Delta l_{i t-j}+\lambda_{3 i} E C T_{i t-1}+\mu_{3 i t} \\
& \Delta o_{i t}=\theta_{4 i}+\sum_{j=1}^{q} \theta_{4,1 i j} \Delta y_{i t-j}+\sum_{j=1}^{q} \theta_{4,2 i j} \Delta r e_{i t-j}+\sum_{j=1}^{q} \theta_{4,3 i j} \Delta n r e_{i t-j}+\sum_{j=1}^{q} \theta_{4,4 i j} \Delta o_{i t-j}+\sum_{j=1}^{q} \theta_{4,5 i j} \Delta k_{i t-j} \\
& \sum_{j=1}^{q} \theta_{4,6 i j} \Delta l_{i t-j}+\lambda_{4 i} E C T_{i t-1}+\mu_{4 i t} \\
& \Delta k_{i t}=\theta_{5 i}+\sum_{j=1}^{q} \theta_{5,1 i j} \Delta y_{i t-j}+\sum_{j=1}^{q} \theta_{5,2 i j} \Delta r e_{i t-j}+\sum_{j=1}^{q} \theta_{5,3 i j} \Delta n r e_{i t-j}+\sum_{j=1}^{q} \theta_{5,4 i j} \Delta o_{i t-j}+\sum_{j=1}^{q} \theta_{5,5 i j} \Delta k_{i t-j} \\
& \sum_{j=1}^{q} \theta_{5,6 i j} \Delta l_{i t-j}+\lambda_{5 i} E C T_{i t-1}+\mu_{5 i t} \\
& \Delta l_{i t}=\theta_{6 i}+\sum_{j=1}^{q} \theta_{6, i i j} \Delta y_{i t-j}+\sum_{j=1}^{q} \theta_{6,2 i j} \Delta r e_{i t-j}+\sum_{j=1}^{q} \theta_{6,3 i j} \Delta n r e_{i t-j}+\sum_{j=1}^{q} \theta_{6,4 i j} \Delta o_{i t-j}+\sum_{j=1}^{q} \theta_{6,5 i j} \Delta k_{i t-j} \\
& \sum_{j=1}^{q} \theta_{6,6 i j} \Delta l_{i t-j}+\lambda_{6 i} E C T_{i t-1}+\mu_{6 i t} \\
& E C T_{i t}=y_{i t}-\hat{\beta}_{1 i} r e_{i t}-\hat{\beta}_{2 i} n r e_{i t}-\hat{\beta}_{3 i} o_{i t}-\hat{\beta}_{4 i} k_{i t}-\hat{\beta}_{5 i} l_{i t}
\end{aligned}
$$

where $\Delta$ is the first difference operator; the autoregression lag length, $q$, is set at one and determined automatically by the Schwarz Information Criterion (SIC); $\mu$ is a random error term; ECT is the error correction term derived from the long-run relationship of Eq. (3).

To investigate the short and long-run dynamic relationships between variables, we follow the two steps of Engle and Granger (1987) approach. First, we estimate the long-run parameters in Eq. (3) in order to get the residuals corresponding to the deviation from equilibrium. Second, we estimate the parameters related to the short-run adjustment of Eqs. (5)-(11). Short-run causality is determined by the significance of F-statistics and the long-run causality corresponding to the error correction term is determined by the significance of $t$ statistics. ${ }^{3}$ The short and long-run Granger causality is analyzed through direct and indirect channels between variables. The Granger causality tests are reported in Tables 6 and 7, and Fig.1 resumes these causalities for our main variables.

\footnotetext{
${ }^{3}$ The error correction term estimates the speed at which the dependent variable converges to the long-run equilibrium after variations of independent variables. The value of lagged ECT is between 0 and -1 .
} 
Table 6. Granger causality tests (model with exports)

\begin{tabular}{|c|c|c|c|c|c|c|c|}
\hline \multirow{2}{*}{$\begin{array}{l}\text { Dependent } \\
\text { variable }\end{array}$} & \multicolumn{6}{|l|}{ Short-run } & \multirow{2}{*}{$\begin{array}{l}\text { Long-run } \\
E C T\end{array}$} \\
\hline & $\Delta y$ & $\Delta r e$ & Anre & $\Delta e x$ & $\Delta k$ & $\Delta l$ & \\
\hline \multirow[t]{2}{*}{$\Delta y$} & - & 0.27709 & 0.09175 & 14.9943 & 0.70006 & 6.15837 & -0.075582 \\
\hline & & $(0.5987)$ & $(0.7620)$ & $(0.0001)^{* * *}$ & $(0.4029)$ & $(0.0132)^{* *}$ & $(0.0034) * * *$ \\
\hline \multirow[t]{2}{*}{$\Delta r e$} & 2.05523 & - & 0.88021 & 0.27543 & 1.07893 & 0.37766 & 0.000726 \\
\hline & $(0.1518)$ & & $(0.3483)$ & $(0.5998)$ & $(0.2991)$ & $(0.5389)$ & $(0.0543)^{*}$ \\
\hline \multirow[t]{2}{*}{ Anre } & 0.87644 & 0.70423 & - & 5.20133 & 0.35917 & 2.99523 & 0.005314 \\
\hline & $(0.3493)$ & $(0.4015)$ & & $(0.0227)^{* *}$ & $(0.5490)$ & $(0.0837)^{*}$ & $(0.0029) * * *$ \\
\hline \multirow[t]{2}{*}{$\Delta e x$} & 34.2832 & 6.52984 & 26.5075 & - & 30.3576 & 1.38140 & -0.082826 \\
\hline & $(0.0000)^{* * *}$ & $(0.0107)^{* *}$ & $(0.0000)^{* * *}$ & & $(0.0000)^{*}$ & $(0.2400)$ & $(0.0000)^{* * *}$ \\
\hline \multirow[t]{2}{*}{$\Delta k$} & 7.83140 & 1.33448 & 1.11353 & 4.35998 & - & 2.38113 & 0.014184 \\
\hline & $(0.0052)^{* * *}$ & $(0.2482)$ & $(0.2914)$ & $(0.0369)^{* *}$ & & $(0.1230)$ & $(0.9040)$ \\
\hline \multirow[t]{2}{*}{$\Delta l$} & 0.03283 & 0.04612 & 0.01208 & 3.62611 & 0.10699 & - & -0.004447 \\
\hline & $(0.8562)$ & $(0.8300)$ & $(0.9125)$ & $(0.0570)^{*}$ & $(0.7436)$ & & $(0.0013) * * *$ \\
\hline
\end{tabular}

"***", "**", and “*” indicate statistical significance at the 1, 5 and $10 \%$ levels, respectively.

Lag lengths selected is 1 based on the Schwarz Information Criterion (SIC).

$\mathrm{P}$-value listed in parentheses.

For the panel VECM with exports, short-run Granger causality tests, reported in Table 6, show that there is evidence of a bidirectional causality between exports and output at the $1 \%$ significance level. There is also a bidirectional short-run causality between exports and nonrenewable energy consumption, which is statistically significant at the $1 \%$ and $5 \%$ levels when the causality runs from non-renewable energy and exports, respectively. A unidirectional short-run causality running from renewable energy consumption to exports is validated at the 5\% significance level. However, there is no evidence of a direct short-run causality between output and renewable energy consumption or between output and nonrenewable energy consumption.

The long-run test results, reported in Table 6, provide that the error correction term is statistically significant at the $1 \%$ level for Eqs. (5), (8) and (10). Let us notice that the computed error correction terms corresponding to the renewable energy and non-renewable energy equations are statistically significant with a slow speed of adjustment while their signs are not negative (estimated coefficients are approximately equal to zero). This means that there is evidence of a long-run causality running: $i$ ) from renewable and non-renewable energy, exports, capital, and labor to output, ii) from output, renewable and non-renewable energy, capital and labor to exports, and iii) from output, renewable and non-renewable energy, exports and capital to labor. We can also deduce that there is a long-run bidirectional causality between output and exports. 
Table.7 Granger causality tests (model with imports)

\begin{tabular}{|c|c|c|c|c|c|c|c|}
\hline \multirow{2}{*}{$\begin{array}{l}\text { Dependent } \\
\text { variable }\end{array}$} & \multicolumn{6}{|l|}{ Short-run } & \multirow{2}{*}{$\begin{array}{l}\text { Long-run } \\
E C T\end{array}$} \\
\hline & $\Delta y$ & $\Delta r e$ & Anre & $\Delta i m$ & $\Delta k$ & $\Delta l$ & \\
\hline \multirow[t]{2}{*}{$\Delta y$} & - & 0.27709 & 0.09175 & 13.2892 & 0.70006 & 6.15837 & -0.037834 \\
\hline & & $(0.5987)$ & $(0.7620)$ & $(0.0003)^{* * *}$ & $(0.4029)$ & $(0.0132)^{* *}$ & $(0.0000)^{* * * *}$ \\
\hline \multirow[t]{2}{*}{$\Delta r e$} & 2.05523 & - & 0.88021 & 0.31788 & 1.07893 & 0.37766 & -0.004406 \\
\hline & $(0.1518)$ & & $(0.3483)$ & $(0.5730)$ & $(0.2991)$ & $(0.5389)$ & $(0.0002)^{* * *}$ \\
\hline \multirow[t]{2}{*}{ Anre } & 0.87644 & 0.70423 & - & 3.43358 & 0.35917 & 2.99523 & 0.011976 \\
\hline & $(0.3493)$ & $(0.4015)$ & & $(0.0640)^{*}$ & $(0.5490)$ & $(0.0837)^{*}$ & $(0.0017)^{* * *}$ \\
\hline \multirow[t]{2}{*}{$\Delta i m$} & 36.1896 & 5.65292 & 30.4427 & - & 26.6078 & 1.64869 & -0.142364 \\
\hline & $(0.0000)^{* * *}$ & $(0.0175)^{* *}$ & $(0.0000)^{* * *}$ & & $(0.0000)^{* * *}$ & $(0.1993)$ & $(0.0000)^{* * *}$ \\
\hline \multirow[t]{2}{*}{$\Delta k$} & 7.83140 & 1.33448 & 1.11353 & 4.05661 & - & 2.38113 & 0.042607 \\
\hline & $(0.0052)^{* * *}$ & $(0.2482)$ & $(0.2914)$ & $(0.0441)^{* *}$ & & $(0.1230)$ & $(0.0348)^{* *}$ \\
\hline \multirow[t]{2}{*}{$\Delta l$} & 0.03283 & 0.04612 & 0.01208 & 2.55519 & 0.10699 & - & -0.000430 \\
\hline & $(0.8562)$ & $(0.8300)$ & $(0.9125)$ & $(0.1101)$ & $(0.7436)$ & & $(0.0002)^{* * *}$ \\
\hline
\end{tabular}

“***", “**”, and "*”" indicate statistical significance at the 1\%, 5\% and $10 \%$ levels, respectively.

Lag lengths selected is 1 based on the Schwarz Information Criterion (SIC).

$\mathrm{P}$-value listed in parentheses.

For the panel VECM with imports, short-run Granger causality tests, reported in Table 7, show that there is evidence of a bidirectional causality between imports and output at the $1 \%$ significance level. There is a bidirectional short-run causality between imports and nonrenewable energy consumption, which is statistically significant at the $1 \%$ and $10 \%$ levels when the causality runs from non-renewable energy and imports, respectively. A unidirectional short-run causality running from renewable energy consumption to imports is validated at the 5\% significance level. However, there is no evidence of a direct short-run causality between renewable energy consumption and output or between non-renewable energy consumption and output.

Table 7 reports the long-run test results which provide that the error correction term is statistically significant at the $1 \%$ level for Eqs. (5), (6), (8) and (10). Notice that the estimated error correction terms concerning the non-renewable energy and capital equations are statistically significant with a slow speed of adjustment while their signs are not negative. This means that there is a long-run causality running: $i$ ) from renewable and non-renewable energy, imports, capital, and labor to output, ii) from output, non-renewable energy, imports, capital and labor to renewable energy, iii) from output, renewable and non-renewable energy, capital and labor to imports, and iv) from output, renewable and non-renewable energy, imports and capital to labor. Also, we deduce that there is a long-run bidirectional causality between output and imports. 


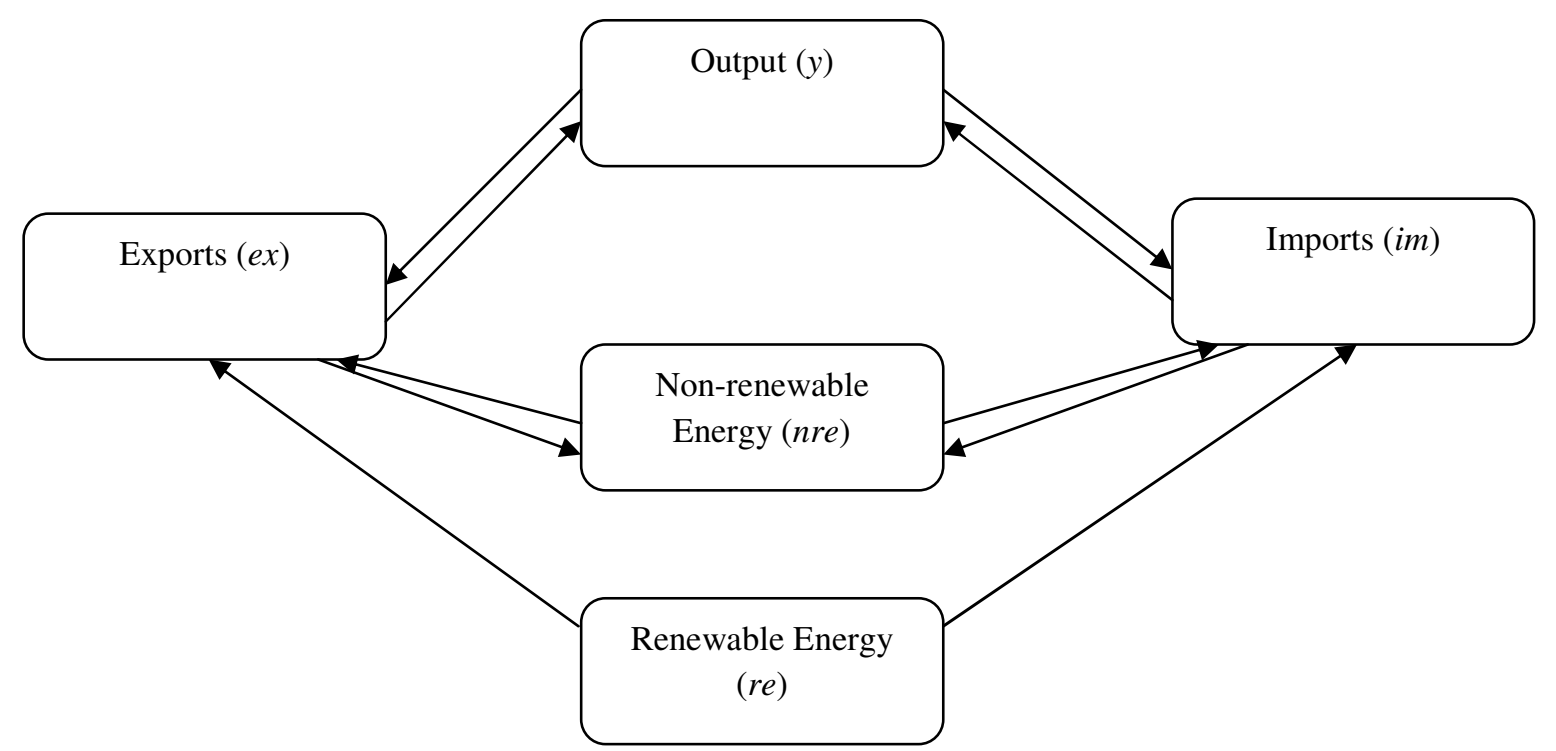

Fig.1. Short-run causality between output, renewable and non-renewable energy and Trade

Fig.1 resumes the short-run Granger causality between our main variables. It shows that there is a short-run bidirectional causality between trade (exports or imports) and output. This signifies that any variation in trade affects output. They suggest that economic growth cannot be realized without more trade openness. These results confirm the findings of Sadorsky (2012) who is concerned by a panel of 7 South American countries, and those of Sadorsky (2011) who is concerned by a panel of 8 Middle Eastern countries.

Our short-run Granger causality tests suggest the existence of a unidirectional causality running from renewable energy consumption to trade, and a bidirectional causality between non-renewable energy consumption and trade. They suggest that any variation in renewable energy consumption affects trade, and that trade expansion cannot be realized without affecting non-renewable energy consumption. These results are new and interesting because this paper is the first temptation to investigate empirically the causal relationship between renewable energy consumption, non-renewable energy consumption and international trade. Nevertheless, in the short-run, Sadorsky (2012) shows the existence of a bidirectional relationship between exports and energy consumption, and a one-way causality from energy consumption to imports.

In the short-run, there is no direct causality between renewable energy consumption and non-renewable energy consumption. However, there is an indirect and unidirectional causality running from renewable energy consumption to non-renewable energy consumption through trade (exports or imports). This means that any variation in renewable energy consumption indirectly affects non-renewable energy consumption. Let us notice that Apergis and Payne (2012) show the existence of a direct short-run bidirectional causality between renewable and non-renewable energy consumption indicative of substitutability between the two energy sources. We think that this direct causality obtained by these authors is mainly due to the omission of the trade variable.

Our Granger causality tests show that there is no direct short-run causality between renewable energy consumption or non-renewable energy consumption and output. However, there is an indirect short-run unidirectional causality from renewable energy to output through trade (exports or imports). Also, there is an indirect short-run bidirectional causality between non-renewable energy and output, which occurs through trade (exports or imports). Our results are not similar to those found by Apergis and Payne (2010a, 2011) as they show the existence of a direct bidirectional relationship between renewable energy consumption and output in both the short and long-run. They also differ from the results of Apergis and Payne 
(2012) whose show the existence of a direct bidirectional relationship between renewable and non-renewable energy consumption and output in both the short and long-run. These differences in results can be explained by two main reasons. The first reason is that the data used in our analysis differ from those used by Apergis and Payne (2010a, 2011, 2012). The second reason is that we incorporate in our study trade openness as an explanatory variable. Moreover, the integration of exports and imports in the production function can divert the direction of causality between variables. Our results of short-run Granger causality show that the relationship between energy consumption and output is not direct, either for renewable or non-renewable energy. Our results confirm those of Sadorsky (2012) who shows that the interconnection between output and energy consumption is not direct. Indeed, in the short-run, he shows the existence of an indirect bidirectional causality between energy consumption and output through exports, and an indirect unidirectional causality from energy consumption to output through imports.

\section{Concluding remarks}

This research studies the causal relationship between output, renewable and nonrenewable energy consumption and trade for a panel of 69 countries over the period 19802007. This study is interesting because there is no previous work that tried to understand the causal relationship between output, international trade and renewable and non-renewable energy consumption.

We consider two models. In each model the dependant variable is GDP (output) and the independent variables are renewable energy consumption, non-renewable energy consumption, trade openness, stock of capital and labor force. In the first model, trade openness is measured by merchandise exports, and in the second model, it is measured by merchandise imports.

Granger causality tests show that there is evidence of a bidirectional causality between output and trade (exports or imports) in both the short and long-run. These results indicate that any changes in trade affect output and any changes in output affect trade. They suggest that economic growth cannot be realized without more trade openness.

Also, there is evidence of a one way short-run causality without feedback running from renewable energy consumption to trade, and a short-run feedback causality between nonrenewable energy consumption and trade. These results suggest that any variation in renewable energy consumption affects trade, and that trade expansion cannot be realized without increasing non-renewable energy consumption. These results are new and interesting because this study is the first temptation to empirically investigate the causal relationship between renewable energy consumption, non-renewable energy consumption and international trade.

We show that there is no direct causality between renewable energy consumption and non-renewable energy consumption. However, we find an indirect and unidirectional causality running from renewable energy consumption to non-renewable energy consumption, which occurs through trade (exports or imports). This means that any variation in renewable energy consumption indirectly affects non-renewable energy consumption. Let us notice that Apergis and Payne (2012) show the existence of a direct short-run feedback causality between renewable and non-renewable energy consumption indicative of substitutability between the two energy sources. We think that this direct causality obtained by these authors is mainly due to the omission of the trade variable. The inclusion of trade variables in our model shows that the causal relationship between renewable and non-renewable energy is indirect, and occurs through trade. 
Our results show that there is no direct short-run causality between renewable and nonrenewable energy consumption and output. However, there is an indirect short-run causality running from renewable and non-renewable energy to output via trade. Thus, in the short-run, renewable and non-renewable energy consumption have an impact on output. Our results are not similar to those found by Apergis and Payne (2010a, 2011) as they show the existence of a direct bidirectional relationship between renewable energy consumption and output in both the short and long-run. They also differ from the results of Apergis and Payne (2012) whose show the existence of a direct bidirectional relationship between renewable and nonrenewable energy consumption and output in both the short and long-run. Our results differ from the above mentioned literature mainly because we have included trade openness as an explanatory variable. However, our results confirm those of Sadorsky (2012) who show that the interconnection between output and energy consumption is not direct, and occurs through trade.

In our long-run estimations, output is the dependent variable. Long-run elasticities are estimated using OLS, FMOLS and DOLS panel approaches. The results of estimations show that all coefficients are positive and statistically significant at mixed level, except for exports coefficient which is statistically significant only with the OLS panel approach. Therefore, in the long-run, any increase in capital, labor force, renewable energy consumption, nonrenewable energy consumption and trade (exports or imports) will increase economic growth.

Our policy recommendations are that countries should opt for more trade openness because this enables them to benefit from technology transfer, economies of scale and to build the human and physical capacities necessary to produce more renewable energies, while increasing their output. Because of the substitutability between renewable energy and nonrenewable energy, more trade openness can reduce the share of non-renewable energy in total energy. Therefore, more trade openness does not mean systematically more pollution. Thus, through technology transfer and economies of scale, more trade openness could be a good policy for combating global warming by encouraging the use of renewable energies, while increasing output.

\section{Appendix: 69 countries sample}

Algeria, Argentina, Australia, Austria, Bangladesh, Belgium, Bolivia, Brazil, Bulgaria, Cameroon, Canada, Chile, China, Comoros, Costa Rica, Denmark, Dominican Republic, Ecuador, Egypt, El Salvador, Finland, France, Gabon, Ghana, Greece, Guatemala, Honduras Hungary, Iceland, India, Indonesia, Iran, Ireland, Italy, Japan, Kenya, Korea Rep, Malawi, Malaysia, Mali, Mauritius, Mexico, Morocco, Mozambique, Netherlands, New Zealand, Nicaragua, Norway, Pakistan, Panama, Paraguay, Peru, Philippines, Portugal, South Africa, Spain, Sri Lanka, Sudan, Swaziland, Sweden, Switzerland, Syria, Thailand, Tunisia, United Kingdom, United States, Uruguay, Venezuela, Zambia. 


\section{References}

Apergis, N., Payne, J.E., 2010a. Renewable energy consumption and economic growth evidence from a panel of OECD countries. Energy Policy, 38, 656-660.

Apergis, N., Payne, J.E., 2010b. Renewable energy consumption and growth in Eurasia. Energy Economics, 32, 1392-1397.

Apergis, N., Payne, J.E., 2011. The renewable energy consumption-growth nexus in Central America. Applied Energy, 88, 343-347.

Apergis, N., Payne, J.E., 2012. Renewable and non-renewable energy consumption-growth nexus: Evidence from a panel error correction model. Energy Economics, 34, 733-738.

Banerjee, A., 1999. Panel data unit roots and cointegration: an overview. Oxford Bulletin of Economics and Statistics, 61 (S1), 607-629.

Breitung, J., 2000. The local power of some unit root tests for panel data, in: B.Baltagi (Ed.) Non-Stationary panels, panel cointegration, and dynamic panels, Advances in Econometrics, 15, 161-178, JAI Press, Amsterdam.

Dickey, D.A., Fuller, W.A., 1979. Distribution of the estimators for autoregressive time series with a unit root. Journal of the American Statistical Association, 74, 427-431.

Engle, R.F., Granger C.W.J., 1987. Co-integration and error correction: Representation, estimation, and testing. Econometrica, 55, 251-276.

Heston, A., Summers, R., Aten, B., 2012. Penn world table version 7.1. Center of comparisons of production, income and prices at the University of Pennsylvania. Accessed at: https://pwt.sas.upenn.edu/php_site/pwt71/pwt71_form.php.

Im, K.S., Pesaran, M.H., Shin, Y., 2003. Testing for unit roots in heterogeneous panels. Journal of Econometrics, 115, 53-74.

International Energy Agency, 2012. Renewable Energy Outlook. Available online at: www.worldenergyoutlook.org/media/weowebsite/2012/WEO2012_Renewables.pdf.

Kao, C., 1999. Spurious regression and residual-based tests for cointegration in panel data. Journal of Econometrics, 90, 1-44.

Lean, H.H., Smyth, R., 2010a. Multivariate Granger causality between electricity generation, exports and GDP in Malaysia. Energy, 35, 3640-3648.

Lean, H.H., Smyth, R., 2010b. On the dynamics of aggregate output, electricity consumption and exports in Malaysia: Evidence from multivariate Granger causality tests. Applied Energy, 87, 1963-1971.

Levin, A., Lin, C.F., Chu, C.S., 2002. Unit root tests in panel data: Asymptotic and finitesample properties. Journal of Econometrics, 108, 1-24.

Narayan, P.K., Smyth, R., 2009. Multivariate Granger causality between electricity consumption, exports and GDP: evidence from a panel of Middle Eastern countries. Energy Policy, 37, 229-236.

Pedroni, P., 1999. Critical values for cointegration tests in heterogeneous panels with multiple regressors. Oxford Bulletin of Economics and Statistics, 61, 653-670.

Pedroni, P., 2001. Purchasing power parity tests in cointegrated panels. Review of Economics and Statistics, 83, 727-731.

Pedroni, P., 2004. Panel cointegration: Asymptotic and finite sample properties of pooled time series tests with an application to the PPP hypothesis. Econometric Theory, 20, 597625.

Phillips, P.C.B., Perron, P., 1988. Testing for a unit root in time series regressions. Biometrika, 75, 335-346.

Sadorsky, P., 2009a. Renewable energy consumption, CO2 emissions and oil prices in the G7 countries. Energy Economics, 31, 456-462. 
Sadorsky, P., 2009b. Renewable energy consumption and income in emerging economies. Energy policy, 37, 4021-4028.

Sadorsky, P., 2011. Trade and energy consumption in the Middle East. Energy Economics, 33, 739-749.

Sadorsky, P., 2012. Energy consumption, output and trade in South America. Energy Economics 34, 476-488.

World Bank, 2010. World Development Indicators. Accessed at: http://www.worldbank.org/data/onlinedatabases/onlinedatabases.html.

United Nations Environment Program and the World Trade Organization, 2009. Trade and Climate Change. Available at http://www.wto.org.

World Trade Organization, 2011. Harnessing trade for sustainable development and a green economy. Available at: www.wto.org. 